Inna Šteinbuka, Normunds Malnačs

\title{
Valsts atbalsts pandēmijas laikā un fiskālās ilgtspējas riski
}

Covid-19 pandēmija izraisija ekonomisko šoku tautsaimniecībā gan piedāvājuma, gan pieprasijuma pusē. Uzṇēmumiem strauji pasliktinājās likviditāte, kā arī radās problēmas ražošanas procesā ieviesto ierobežojumu iespaidā un izejvielu piegāžu ķežu pārrāvumu dēḷ. Savukārt pieprasijjums strauji samazinājās gan ieviesto ierobežojumu, gan daudzu iedzīvotāju ienākumu krituma dẹḷ. Lielās nenoteiktības apstākḷos investīciju projekti tika atcelti vai atlikti. Šie apstākḷi diktēja nepieciešamību pēc aktīvas valsts iejaukšanās ar fiskālās politikas instrumentiem, kas nodrošinātu gan ekonomikas potenciāla saglabāšanu un veselības sektora kapacitātes palielināšanu, gan iedzìvotāju izdzīvošanu ienākumu neesamības vai krituma dēḷ. Šajā pētījumā tiek raksturota Latvijas valsts atbalsta programma pandēmijas krīzes laikā salīdzinājumā ar citām ES dalībvalstīm, sniegts Latvijas fiskālās situàcijas izmaiṇu novērtējums krīzes laikā un analizēti fiskālās ilgtspējas riski.

\section{Latvijas valsts atbalsts Covid-19 krīzes laikā}

Latvijā ekonomikas sabremzēšanās sākās 2019. gada otrajā pusē strukturālo problēmu un darbaspēka trūkuma dēḷ, kas rezultējās rūpniecības sektora produkcijas un eksporta apjoma palēnināšanā. Turklāt tranzīta kritums un kardinālas regulējuma izmaiṇas banku sektora ietekmēja izaugsmi un palielināja pandēmijas šoka ietekmi. IKP saruka 2020. gada pirmajā ceturksnī, bet otrajā kritums sasniedza zemāko punktu (-8,9\% no IKP). Igaunijas ekonomikas kritums otrajā ceturksnī (-6,9\%) bija maigāks salīdzinājumā ar Latviju. Savukārt 
Lietuvā spēcīgā ekonomikas izaugsme 2019. gada nogalē nodrošināja ekonomikas izaugsmi arī 2020. gada pirmajā ceturksnī un mazāku ekonomikas kritumu (tikai $-4,6 \%$ ) otrajā ceturksnī. Vidējais IKP kritums ES valstīs otrajā ceturksnī bija $-14 \%$.

Starptautiskās institūcijas un vadošie pasaules ekonomisti bija vienprātīgi savos secinājumos, ka fiskālā politika ir viens no galvenajiem instrumentiem Covid-19 izraisītās krīzes pārvarēšanā. Svarīga ir pareiza fiskālo instrumentu izvēle, lai ekonomiskā atlabšana notiktu iespējami efektīvāk un ar iespējami mazāku iespaidu uz valsts budžeta bilanci un parāda līmeni. Globālo finanšu krīzi 2008. gadā izraisija ekonomikas pārkaršana pārmērīga kopējā pieprasijuma dēl gan Latvijā, gan kopumā pasaulē, kuru bija iespējams pārvarēt, konsolidējot izdevumus, taču Covid-19 izraisītā krīze ir pārvarama, valdībai un Eiropas Centrālajai bankai (ECB) rīkojoties pretcikliski un stimulējot ekonomiku.

Sākoties krīzei, ECB operatīvi paziņoja par 750 mljrd. EUR apjomīgu pandēmijas ārkārtējās situācijas aktīvu uzpirkšanas programmu, kas tiktu îstenota līdz 2020. gada beigām. ${ }^{1}$ Arī Eiropas Komisija nekavējoties aktivizēja ES Stabilitātes un izaugsmes pakta vispārējā izṇēmuma klauzulu, kas ḷāva dalībvalstīm palielināt vispārējās valdības budžeta deficītu 2020. gadā tik daudz, cik nepieciešams Covid-19 pandēmijas izsauktā ekonomikas kaitējuma mazināšanai. ES noteikumi par valsts atbalstu ḷāva arī sniegt finansiālo atbalstu uzṇēmumiem² ${ }^{2}$ tostarp, piemēram, aviācijas nozarei, kas normālos apstākḷ los nebūtu iespējams.

Pasaules ekonomisko križu vēsture parāda: ja valsts izveidotie stabilizācijas un atbalsta pasākumi nav pietiekami efektīvi vai labi mērḳēti makroekonomiskā šoka gadījumā, tas var izraisīt arī finanšu sektora krīzi, kas veicina masveida bankrotus, rezultējas banku sektora kapitāla nepietiekamībā un vēl vairāk pasliktina makroekonomisko situāciju. Covid-19 izraisītā ekonomiskā krīze diktēja nepieciešamību pēc fiskālās stimulěšanas, kas atbilstu trīs pamatkritērijiem: tai jābūt a) savlaicīgai un pēc iespējas operatīvai; b) labi mērḳētai uz visiem ekonomikas segmentiem un iedzivotāju grupām, kas cietuši no krīzes; c) uz ierobežotu laiku. N̦emot vērā krīzes izraisīšanas epidemiologisko raksturu, bija skaidrs, ka veselības nozares kapacitātes stiprināšanai ir jābūt vienam no fiskālās ekspansijas virzieniem, it sevišķi n,emot vērā, ka Latvijā veselības aprūpes nozarei hroniski trūka finansējuma.

1 ECB announces $€ 750$ billion Pandemic Emergency Purchase Programme (PEPP): https://www.ecb.europa.eu/press/pr/date/2020/html/ecb.pr200318_1 3949d6f266.en.html [skatīts 24.03.2021.]

2 Communication from the Commission. Temporary Framework for State aid measures to support the economy in the current COVID-19 outbreak: https:/ec.europa.eu/competition/state_aid/what_is_ new/sa_covid19_temporary-framework.pdf [skatits 07.03.2021.] 
Pēc ekspertu novērtējuma, Latvijas valdības rīcība kopumā atbilda visiem trim iepriekš pieminētajiem kritērijiem, vismaz pirmā Covid-19 viḷṇa laikā. Valdỉbas reakcija uz Covid-19 pirmo vilni bija salīdzinoši ātra, un jau martā valsts sāka izveidot atbalsta instrumentus, un finanšu līdzekḷi sāka sasniegt adresātus. Atbalsta mehānismi bija mērķēti gan uz pieprasījuma, gan piedāvājuma uzturēšanu, arī atbalsta saṇēmēji ietvēra visus ekonomiskās un sociālās dzīves subjektus iedzīvotājus, darbaspēku, uzṇēmējus, veselības aizsardzības sektora institūcijas un nevalstisko sektoru, ieskaitot religiskās organizācijas. Atbalsta instrumenti tika limitēti laikā tā, lai tie neietekmētu budžeta bāzi un darbotos tikai krīzes periodā.

Atbalsta pasākumus nosacìti var iedalìt 5 grupās pēc to veida: a) nodokḷu jomā; b) pabalstu jomā; c) aizdevumu un garantiju jomā; d) nozaru griezumā; e) ES finansētais atbalsts. No fiskālās politikas viedokḷa vēl svarīgāks ir atbalsta iedalījums pēc ietekmes uz vispārējo valdības budžeta bilanci divās grupās: diskrecionārie pasākumi ar tiešu ietekmi uz vispārējo valdības budžeta bilanci budžeta izdevumu vai nodokḷu samazināšanas veidā un likviditātes pasākumi (garantijas, kredīti) ar netiešu ietekmi. Likviditātes pasākumiem ir neliela ietekme uz vispārējo valdības budžeta bilanci ìstermiṇā, lai arī vidējā termiņā tiem ir potenciāls ietekmēt budžeta bilanci, ja kredīts netiek atdots vai garantija tiek aktivizēta.

Salīdzinoši veiksmīgā valdības darbība Covid-19 pirmā viḷnna laikā un paḷaušanās, ka otrais vilnis varētu arī neatnākt, "iemidzināja" valdības modrību, un tās darbības krīzes otrā viḷnna apkarošanā saṇēma daudz kritikas. Piemēram, Fiskālās disciplīnas padome savā 2020. gada decembrī krīzes monitoringẩ ${ }^{3}$ atzīmē, ka "padome vēlētos, lai valdības rīcība Covid-19 otrā viḷnna krīzes seku novēršanā būtu preventīvāka un ātrāka". Valsts atbalsta pasākumi otrā viḷna sākumā nesasniedza plānotos apjomos, un valdība, konsultējoties ar uzṇēmējiem, mīkstināja pabalstu saņemšanas kritērijus un palielināja atbalsta apjomu. Tad valdība sabiedrības spriedzes mazināšanas nolūkā strauji palielināja atbalsta apjomus iedzīvotājiem (vienreizējs atbalsts ǵimenēm ar bērniem un pensionāriem), kā arī tautsaimniecības siltināšanas nolūkā izlēma atbalstīt augtās gatavības stadijā esošos būvniecības projektus. Fiskālās disciplīnas padome secināja $a^{4}$, ka "valdība no pārāk maza atbalsta sliecas uz otru galējību - pārāk lieliem izdevumiem. Padomi satrauc plānoto budžeta izdevumu pieauguma temps un apjoms, atbalsts aizvien vairāk izskatās politiski, nevis ekonomiski pamatots". Sevišķi ekonomiski un

Monitoringa ziņojums Nr. 10. Pieejams: https://www.fdp.gov.lv/lv/media/1209/download [skatīts 29.03.2021.]

4 Monitoringa ziṇojums Nr. 12. Pieejams: https://www.fdp.gov.lv/lv/media/1653/download [skatīts 29.03.2021.] 
sociāli nepamatots izskatās papildu valsts pasūtỉjums būvniecības nozarei ${ }^{5}$ vairāk nekā 200 miljonu eiro apmērā, ņemot vērā, ka būvniecības nozare ir viena no retajām, kas piedzīvoja izaugsmi 2020. gadā, un 2021. gadā tiek plānoti vērienīgi būvniecības darbi saistībā ar Rail Baltica projektu. Piedevām, pēc VID novērtējuma $^{6}$, neraugoties uz pieaugumu būvniecības nozarē 2020. gadā (+4\% faktiskajās cenās), tās nomaksātie nodokḷi valsts budžetā ir samazinājušies par 22,8\%. Neizskaidrojams iekasēto nodokḷ kritums nav bijis par šķērsli šīs nozares uzṇēmumiem būt vieniem no lielākajiem valsts atbalsta saņēmējiem dỉkstāves, algas subsīdiju un apgrozāmo grantu jomā (7,3\% no kopēja atbalsta).

Valsts atbalsta pasākumu ietekmi uz ekonomiku un valsts budžetu ilustrē 1. tabula.

\section{1. tabula. Valsts atbalsta programmas pasākumu apkopojums un to ietekme uz vispārējo valdības budžeta bilanci}

\begin{tabular}{|c|c|c|c|c|c|c|}
\hline \multirow[t]{2}{*}{$\begin{array}{l}\text { Atbalsta } \\
\text { pasäkumi }\end{array}$} & \multicolumn{3}{|c|}{$\begin{array}{l}\text { Atbalsts ekonomikai } \\
\text { (milj. eiro; \% no IKP) }\end{array}$} & \multicolumn{3}{|c|}{$\begin{array}{c}\text { letekme uz vispārējo valdības } \\
\text { budžeta bilanci } \\
\text { (milj. eiro; \% no IKP) }\end{array}$} \\
\hline & $\begin{array}{c}2020 \\
\text { izpilde }\end{array}$ & $\begin{array}{l}2021 \\
\text { plāns }\end{array}$ & $\begin{array}{c}2021 \\
\text { izpilde* }\end{array}$ & $\begin{array}{l}2020 \\
\text { izpilde }\end{array}$ & $\begin{array}{l}2021 \\
\text { plāns }\end{array}$ & $\begin{array}{c}2021 \\
\text { izpilde* }^{*}\end{array}$ \\
\hline Nodokḷu jomā & $\begin{array}{c}226 \\
(0,9 \%)\end{array}$ & $\begin{array}{c}110 \\
(0,4 \%)\end{array}$ & 31 & $\begin{array}{c}-142 \\
(-0,5 \%)\end{array}$ & $\begin{array}{c}-24 \\
(-0,1 \%)\end{array}$ & -9 \\
\hline Pabalstu jomā & $\begin{array}{c}130 \\
(0,4 \%)\end{array}$ & $\begin{array}{c}563 \\
(1,8 \%)\end{array}$ & 85 & $\begin{array}{c}-130 \\
(-0,4 \%)\end{array}$ & $\begin{array}{c}-563 \\
(-1,8 \%)\end{array}$ & -85 \\
\hline $\begin{array}{l}\text { Aizdevumi un } \\
\text { garantijas }\end{array}$ & $284(1 \%)$ & $\begin{array}{c}903 \\
(2,9 \%)\end{array}$ & 18 & $\begin{array}{c}-195 \\
(-0,7 \%)\end{array}$ & $\begin{array}{c}-89 \\
(-0,3 \%)\end{array}$ & -5 \\
\hline Atbalsts nozarēm & $\begin{array}{c}632 \\
(2,2 \%)\end{array}$ & $\begin{array}{c}1273 \\
(4,2 \%)\end{array}$ & 136 & $\begin{array}{c}-632 \\
(-2,2 \%)\end{array}$ & $\begin{array}{l}-1230 \\
(-4 \%)\end{array}$ & -136 \\
\hline ES fondu finansējums & $27(0,1 \%)$ & $0(0 \%)$ & 1 & $0(0 \%)$ & $-9(0 \%)$ & 0 \\
\hline Kopā & $\begin{array}{c}1329 \\
(4,5 \%)\end{array}$ & $\begin{array}{c}2849 \\
(9,3 \%)\end{array}$ & 271 & $\begin{array}{l}-1098 \\
(-3,7 \%)\end{array}$ & $\begin{array}{l}-1915 \\
(-6,3 \%)\end{array}$ & -236 \\
\hline
\end{tabular}

Avots: Finanšu ministrijas un autoru aprēḳini ( ${ }^{\star}$ dati uz 15.03.2021.).

5 Informatīvais ziņojums. Pieejams: http://tap.mk.gov.lv/lv/mk/tap/?pid=40499551\&mode $=$ mk\&date $=$ 2021-03-18 [skatīts 28.03.2021.]

6 VID prezentācija Saeimas Publisko izdevumu un revīzijas komisijas 2021. gada 23. marta sēdē. Pieejams: https://titania.saeima.lv/livs/saeimasnotikumi.nsf/0/E373868D4CC9235EC225869B00537F23?OpenDocument [skatīts 28.03.2021.] 
No 1. tabulas var izdarīt divus secinājumus. Pirmkārt, valsts atbalsts Covid-19 otrā viḷna periodā tiek plānots daudz lielāks nekā pirmajā vilnī. Jau 2021. gada marta vidū atbalsta apjoms ir bijis vairāk nekā divas reizes lielāks nekā pirmajā vilnī ar attiecīgi lielāku ietekmi uz budžeta deficītu. Lai arī ir faktori, kas apstiprina nepieciešamību pēc lielāka atbalsta otrajā vilnī (uzkrātais sabiedrības nogurums, garāks ārkārtējās situācijas periods), dažu ekonomistu secinājumi vedinātu domāt par mazāka atbalsta nepieciešamību. Piemēram, ESAO ekonomists Nikolas Vološko (Nicolas Woloszko), piemērojot metodologí$\mathrm{ju}^{7}$, kas izmanto Google meklēšanas datus, ir novērtējis, ka Eiropas ekonomikas Covid-19 pirmā viḷna laikā ir strādājušas apmēram $80 \%$ kapacitātē, kamēr otrā viḷna laikā - 90\% kapacitātē. Kà trīs galvenie iemesli tiek minēti mazākas sabiedrības bailes no vīrusa, efektīvāka un precīzāka valdības politika un uzṇēmēju adaptācija jaunajiem apstākḷiem. Lielāka ekonomiskā aktivitāte varētu norādīt uz nepieciešamību pēc mazākas valsts iejaukšanās ar fiskālo politiku.

Otrkārt, otrā vil̦na fiskālais atbalsts sasniegs savus adresātus relatīvi vēlu. Vairāk nekā 4 mēnešus kopš ārkārtējās situācijas sākuma (2021. gada marta vidū) atbalsts ir izmaksāts mazāk nekā 10\% apmērā no kopējā plānotā atbalsta apjoma 2021. gadā. Lìdz ar to lielākā daḷa atbalsta sasniegs savus adresātus jau pēc ārkārtējās situācijas beigām, kad ekonomika, spriežot pēc pirmā viḷna pieredzes, jau funkcionēs ievērojami tuvāk ierastajai kapacitātei. Neapšaubāmi, lai iedarbinātu dažus atbalsta instrumentus, ir nepieciešams daudz garāks laika periods. Tomēr lielākais atbalsts ir nepieciešams tieši krīzes epicentrā. Lìdz ar to cerams, ka šī krīze dos pieredzi valsts pārvaldei iedarbināt atbalsta mehānismus pēc iespējas operatīiāk nākamās potenciālās krīzes gadījumā.

Viens no galvenajiem jautājumiem fiskālā stimula novērtējumā - vai tā apjoms ir bijis adekvāts ekonomiskajai situācijai. Pēc CSP datiem ${ }^{8}$, IKP kritums 2020. gadā sasniedza 1,1 miljardu eiro (3,7\% no IKP), kas ir precīzi salīdzināms ar valdības īstenoto atbalsta pasākumu ietekmi uz vispārējo valdības budžeta bilanci - arī 1,1 miljarda apmērā 2020. gadā. Atbalsta apjoms ir bijis identisks Covid-19 krīzes radīto negatīvo izlaižu starpỉbai ekonomikā. Savukārt šogad, pēc Finanšu ministrijas novērtējuma ${ }^{9}$, IKP pieaugums varētu sasniegt 1,3 miljardus eiro, atbalsta pasākumu ietekme uz budžeta bilanci - 1,9 miljardus eiro $(6,2 \%$ no

Tracking activity in real time with Google Trends. Pieejams: https://www.oecd-ilibrary.org/docserver/6b9c7518- en.pdf?expires $=1614514308 \&$ id =id\&accname $=$ guest\&checksum $=$ A1ED81764886FC4D33562F142A6F90FF [skatīts 28.02.2021.]

8 CSP dati. Pieejams: https://stat.gov.lv/lv/statistikas-temas/valsts-ekonomika/ikp-gada/tabulas/ikp 020-iekszemes-kopprodukts-no-razosanas?themeCode=IK [skatīts 29.03.2021.]

9 Stabilitātes programmas 2021.-2024. gadam dati. Pieejams: https://www.fm.gov.lv/lv/media/6587/ download 


\section{1. attēls. Baltijas valstu atbalsta pasākumu ietekme uz tautsaimniecību Covid-19 pirmā viḷṇa laikā (\% no IKP)}

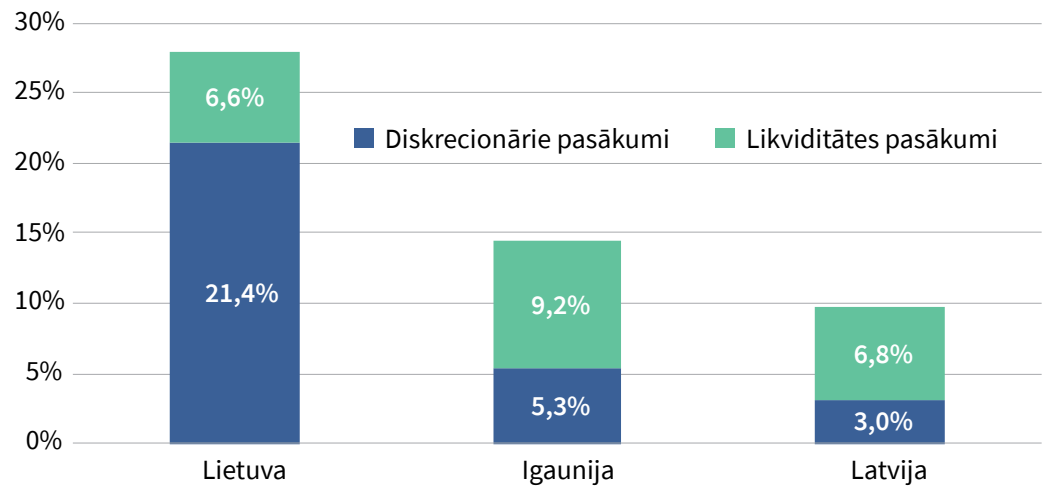

Avots: Eiropas fiskālais monitors (2020, septembris).

IKP). Tas vēlreiz liecina par ievērojami lielāku valsts atbalsta līmeni Covid-19 otrā viḷņa laikā.

ES neatkarīgo fiskālo iestāžu tīkla ziņojums "Eiropas fiskālais monitors, septembris 2020"10 liecina, ka Latvijas atbalsta politika Covid-19 laikā bijusi vismērenākā starp Baltijas valstīm (1. attēls). Latvijas diskrecionārie pasākumi Covid-19 pirmā viḷna laikā bija 3\% no IKP, kamēr Igaunijā un Lietuvā - attiecīgi $5,3 \%$ un $21,4 \%$ no IKP. ${ }^{11}$

Latvijas izdevumi, saistīti ar likviditātes pasākumiem, kas lielākā mērā sastāv no aizdevumiem un garantijām, bija 6,8\% no IKP, tuvu vidējam ES līmenim, bet Igaunijā un Lietuvā - attiecīgi 9,2\% un 6,6\%. Pēc pētījuma aprēḳiniem, kopumā vidēji ES valstis ir stimulējušas savas ekonomikas 7\% apmērā no IKP ar tiešajiem atbalsta pasākumiem un 14\% apmērā no IKP ar netiešajiem pasākumiem.

Latvijas produktivitātes ziņojums ${ }^{12}$ savukārt salīdzina ES valstu atbalsta intensitāti savām ekonomikām un iedzīvotājiem ar kumulatīvo Covid-19 izplatību un secina, ka "Latvijas atbalsta programma izskatās ḷoti samērīga ar Covid-19 izplatību”.

10 European Fiscal Monitor. September, 2020. Pieejams: https://www.euifis.eu/download/efm.pdf [skatīts 09.04.2021.]

11 Šāds salīdzinājums jāvērtē uzmanīgi, jo datu ievākšana katrā valstī var atškirirties. Piemēram, Lietuvā investīciju programmas paātrināta ieviešana pieskaitīta pie atbalsta.

12 Izvērtējums par attālinātā darba ietekmi uz produktivitāti ilgtermiṇā un priekšlikumu sagatavošana produktivitātes paaugstināšanai attālinātā darba apstāḳ̣os. Pieejams: https://www.em.gov.lv/lv/media/4223/download [skatīts 09.04.2021.] 
Situācija strauji mainās jau 2021. gada martā, kad Eiropas fiskālais monitors $^{13}$ secina, ka 2021. gadā Latvijā diskrecionāro jeb tiešo atbalsta pasākumu ietekme uz vispārējo valdības budžeta bilanci būs visaugstākā ES un sasniegs $5,4 \%$ no IKP. Lietuvā šis rādītājs ir apmēram $2 \%$, Igaunijā - $1 \%$, vidējais ES valstīs - 2\%. 2021. gada marta vidū atbalsta pasākumu ietekme uz budžetu sasniegs jau $6,2 \%$. Protams, šie novērtējumi atškirsies no reālajiem rezultātiem gada beigās, un ir iespējamas novirzes dažādu datu ievākšanas metodologijias dẹl, tomēr liecina par Latvijas atbalsta programmas ievērojamo apjomu otrā viḷna laikā.

Starptautiskais salīdzinājums apstiprina secinājumu, ka Latvijas valdības atbalsta programma bija laikā un adekvāta Covid-19 pirmā viḷna periodā. Latvijas ekonomikas kritums visa 2020. gada griezumā bija mērens (-3,6\%), kas ir mazāks nekā vidēji ES (-6,1\%) un mazāks, nekā Finanšu ministrija prognozēja pavasarī (-7\%). Tomēr salīdzinājumā ar kaimiṇvalstīm Latvijas IKP kritums bija straujāks: Lietuvā IKP kritums 2020. gadā sasniedza tikai 0,9\%, Igaunijā - 2,9\%. Tas varētu būt dal̦eji izskaidrojums ar Latvijas valsts atbalsta apjoma atpalicību no Baltijas kaimiņvalstīm pandēmijas pirmā viḷņa laikā.

Savukārt otrā viḷna laikā Latvijas atbalsta programmas apjoms plānots nesamērīgs ar ekonomikas kritumu.

\section{Latvijas fiskālā pozīcija un regulējums}

Pēc ES novērtējuma ${ }^{14}$, Latvijas budžeta deficits 2020. gadā sasniedza $-4,5 \%$ no IKP. Igaunijā budžeta deficīts ir nedaudz augstāks (-4,9\%), Lietuvā - gandrīz par 3 procentpunktiem augstāks (-7,4\%). Latvijas valsts parāds, kas ir ievērojami palielinājies 2020. gadā un sasniedza 43,5\% no IKP, uz citu ES valstu fona ir joprojām salīdzinoši zems.

2021. gada Latvijas budžets tika apstiprināts ar vienu no mazākajiem deficītiem ES - 3,9\% no IKP, kurš saskaṇā ar Fiskālās disciplīnas padomes novērtējumu veidots atbilstoši valdības fiskāli konservatīvajai ideologijiai, tomēr atspoguḷo arī sociālu ievirzi, kas ir īpaši svarīga pandēmijas krīzes laikā. ${ }^{15}$ Tomēr 2021. gada plānotā papildu valsts atbalsta programma var ievērojami pasliktināt budžeta deficītu, un Finanšu ministrijas Stabilitātes programmā ${ }^{16}$ deficìta līmeni jau plāno

13 European Fiscal Monitor (March, 2021). Pieejams: https://www.euifis.eu/eng/fiscal/299/european-fiscal-monitor-march-2021 [skatīts 29.03.2021.]

14 Spring 2021 Economic Forecast: Rolling up sleeves. Pieejams: https:/ec.europa.eu/commission/ presscorner/detail/en/ip_21_2351 [skatīts 12.05.2021.]

15 Monitoringa ziņojums Nr. 10. Pieejams: https://www.fdp.gov.lv/lv/media/1653/download; https://www. fdp.gov.lv/lv/media/1209/download [skatìts 30.03.2021.]

16 Stabilitātes programmas 2021.-2024. gada dati. Pieejams: https://www.fm.gov.lv/lv/media/6587/download 


\section{2. attēls. ES valstu prognozētais parāda līmenis 2021. gada beigās}

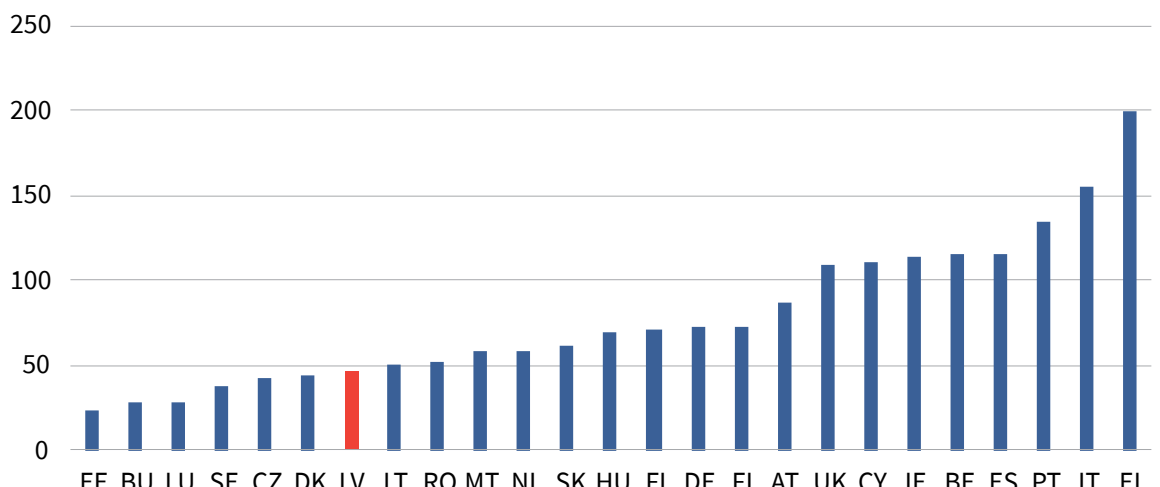

Avots: Eiropas fiskālais monitors (2021, marts).

9,3\% apmērā, kas palielinātu valsts parādu līdz 49\% (47,3\% pēc EK novērtējuma) 2021. gada beigās. Tomēr, salīdzinot ar citām ES dalībvalstīm, Latvijas valsts parāda līmenis 2021. gadā ir septītais zemākais (2. attēls). 2020. gadā ES viszemākais valsts parāds ir bijis Igaunijā (18,2\% no IKP), un Igaunijai ir visas iespējas saglabāt šo vietu arī turpmāk, jo ir paredzēts, ka 2025. gadā valsts parāds sasniegs tikai $28,8 \%$.

Pieņemot, ka Covid-19 izraisìtā ekonomiskā krīze tiks pārvarēta līdz 2021. gada beigām un, jau sākot no 2022. gada, ekonomika atgriezīsies uz izaugsmes ceḷa, nevajadzētu būt pārmērīgām bažām par Latvijas valsts parāda pārmērīgo pieaugumu krīzes laikā un fiskālās ilgtspējas apdraudējumu. Piedevām, pateicoties eiro ieviešanai un atbildīgai fiskālajai politikai pēdējos gadus, Latvija var aizņemties starptautiskos finanšu tirgos ar vēsturiski zemām procentu likmēm, kas ievērojami atvieglo parāda apkalpošanu. 3. attēlā parādīts, kā samazinās vispārējās valdības parāda apkalpošanas izmaksas, neskatoties uz parāda pieaugumu nominālā izteiksmē.

Valsts parāda pieaugums Latvijas un citās ES dalībvalstīs ir likumsakarīgs. Normālos apstākḷıs Latvijas fiskālos nosacijumus nosaka gan ES prasības, gan Latvijas likumi. Stabilitātes un izaugsmes pakts (SiP) nosaka divus galvenos dalībvalstu fiskālos rādītājus - maksimāli piel̦aujamais budžeta deficīts ne lielāks par 3\% un valsts parāds ne lielāks par 60\% no IKP. Savukārt vēlāk ieviestais Fiskālais pakts nosaka, ka valstīm jāpanāk, lai to budžeta gada strukturālais deficīts nepārsniedz 0,5\% vai 1\% (atkarībā no valsts parāda līmeņa) no IKP. Pandēmijas 


\section{3. attēls. Vispārējās valdības parāda apkalpošanas izmaksu dinamika}

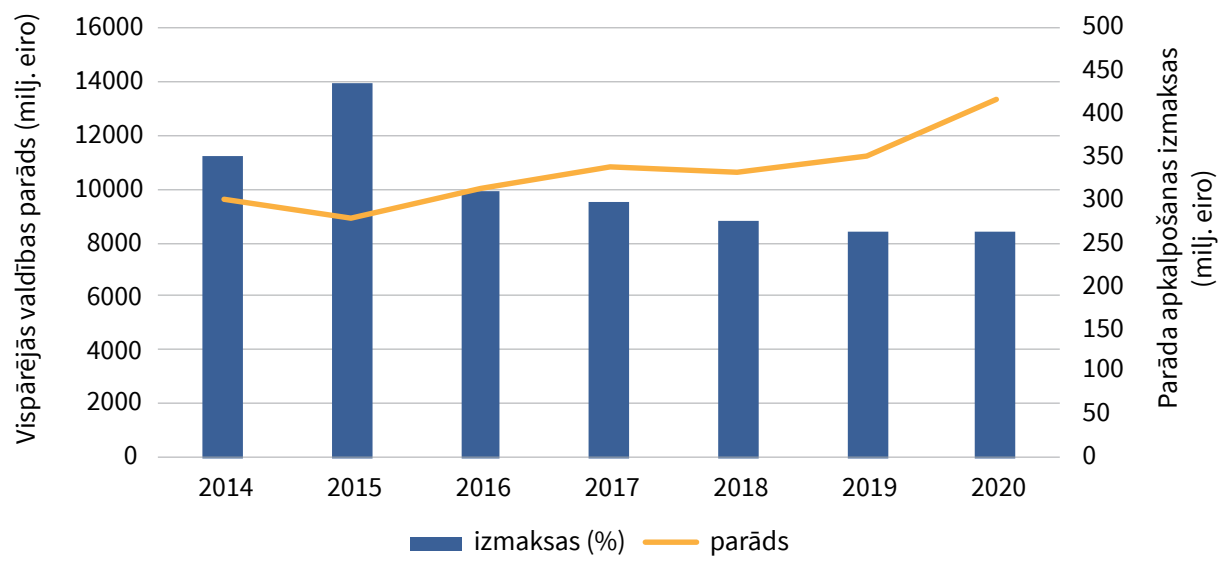

Avots: Valsts kases un Finanšu ministrijas dati.

krīzes laikā, 2020. un 2021. gadā, ir atcelti gan ES, gan Latvijas fiskālie ierobežojumi. Pēc būtības valstis var tērēt budžeta līdzekḷus tik, cik tās uzskata par vajadzīgu, lai izietu no ekonomiskās krīzes. Nesen EK ir publicējusi Fiskālas vadlīnijas ${ }^{17}$, kas satur priekšlikumus dalībvalstu fiskālajai stratēgijai. Lai gan ES valstu parāds tuvojas jau 100\% robežai, vadlīnijas paredz, ka ES fiskālie nosacījumi nebūs spēkā arī 2022. gadā, kaut gan EK aicina pakāpeniski samazināt atbalsta pasākumus, lai atgrieztos pie fiskālās ilgtspējas, vienlaikus nesabremzējot ekonomisko atvesel̦ošanos. Tas raisa zināmas bažas, jo veicinās valdību turpmāku neierobežotu sabiedriskās naudas tērēšanu pat ekonomiskās izaugsmes laikā, neraugoties uz uzkrāto lielo parāda apjomu.

Jau vairākus gadus ES līmeni notiek diskusijas par nepieciešamību mainīt ES fiskālo regulējumu, jo pašreizējais vairs neatbilstot krīzes un pēckrīzes reālijām. Lielākā daḷa ES valstu pārkāpj vienu no galvenajiem Māstrihtas kritērijiem valsts parāda maksimāli pieḷaujamo lielumu 60\% apmērā no IKP. 2012. gadā pieņemtais Fiskālais pakts teorētiski bija pareizs solis, jo noteica budžeta izdevumu griestus atkarībā no ekonomikas cikla. Tomēr strukturālās bilances mērījumi piel̦auj plašu subjektivitātes devu, vēl jo vairāk - tika ieviestas dažādas, arī subjektīvi interpretējamas, atkāpes strukturālo reformu dēḷ, kas vēl vairāk sarežgíja valstu fiskālo nosacījumu kontroli un deva valdībām iespējas neievērot noteiktos

17 Communication from the Commission to the Council. One year since the outbreak of COVID-19: fiscal policy response. Pieejams: https:/ec.europa.eu/info/sites/info/files/economy-finance/1_ en_act_part1_v9.pdf [skatits 01.03.2021.] 
budžeta izdevumu griestus. Tādējādi ES valstis sistemātiski pārkāpa fiskālos nosacijumus - neviena no tām nav tikusi sodìta ${ }^{18}$, un jau pirms Covid-19 ekonomiskās krīzes lielākā daļa valstu pārkāpa valsts parāda $60 \%$ slieksni.

Eiropas fiskālās padomes (European fiscal board) eksperti savā gadskārtējā konferencē 2021. gada 11. martā diskutēja par nepieciešamību reformēt ES dalībvalstu fiskālo uzraudzību, ņemot vērā gan pirmskrīzes, gan krīzes perioda pieredzi. Tika identificēti trīs nepieciešamie elementi, lai uzlabotu ES dalïbvalstu fiskālās politikas uzraudzību: a) centrālā fiskālā vadība; b) investīciju aizsardzības mehānisms; c) reformēts Stabilitātes un izaugsmes pakts (SiP). Eiropas Savienībā joprojām trūkst fiskālo instrumentu, lai ātri un efektīvi reaǵētu uz ekonomikas šoku. Covid-19 pandēmijas krīze skaidri parādīja, ka bez centralizētas, ar dalībvalstīm koordinētas, fiskālās rīcỉbas eirozonai būs ārkārtīgi grūti atgriezties pie fiskālās ilgtspējas pēc krīzes. Savukārt 2008. gada finanšu krīzes novērojums liecina, ka budžeta izdevumu konsolidācijas nepieciešamības gadījumā visbiežāk tiek samazinātas tieši produktīvās investīcijas, kas nosaka nepieciešamību pēc to aizsardzības. Tiek plānots, ka SiP tiktu vienkāršots ar trīs pamatelementiem: a) katrai valstij specifisks vidēja termiṇa parāda līmeṇa mērḳis ar galamērḳi 60\% no IKP; b) izdevumu pieauguma mērḳis; c) izņēmumu klauzula (ekonomiskā krīze, negaidīti notikumi). N̦emot vērā Latvijas salīdzinoši labo fiskālo situāciju, ES izmaiṇas fiskālajā regulējumā un pārraudzībā, domājams, neradīs grūtības pielāgoties jaunajiem apstākḷiem.

\section{Latvijas fiskālās ilgtspējas riski}

Kaut gan Latvijas fiskālās pozīcijas ir samērā labas uz citu ES valstu fona, tomēr publisko finanšu ilgtspēja nākotnē ir aktuāls jautājums. Sabiedrības kopīgās naudas tērēšana, it sevišķi uz nākamo paaudžu rēķina, lai risinātu pašreizējās problēmas, ir vieglāks cel̦š nekā strukturālo reformu veikšana. Var prognozēt, ka, beidzoties Covid-19 krīzei, valsts parāds būs bīstami tuvu 60\% robežai un aktualizēsies izaicinājums to mazināt vai vismaz nepalielināt, lai būtu drošỉbas spilvens nākamo krī̌̌u gadījumā. Vienkāršoti valsts parāda ilgtspēju var izteikt ar formulu:

$$
s=b\left(\frac{r-g}{1+g}\right)
$$

kur $s$ - primārā bilance,

$b$ - parāda līmenis (\% no IKP),

$r$ - parāda apkalpošanas procentu likme,

$g$ - IKP nominālā izaugsme, 
No tās var redzēt, ka parāds ir ilgtspējīgs, ja budžeta primārā bilance spēj adekvāti reagèèt uz parāda līmeṇa reizinājumu ar procentu likmes un IKP nominālās izaugsmes starpību. Zemu procenta likmju un samērīgas ekonomiskās izaugsmes gadijjumā ar sabalansētu primāro bilanci parāda apjoms IKP izteiksmē pat samazināsies, to neatmaksājot. Formula arī norāda uz trīs galvenajiem faktoriem, kas nosaka parāda dinamiku, - budžeta bilance, IKP pieaugums, procentu likmes. Protams, visus trīs faktorus ietekmē politiskie un ekonomiskie faktori, kas atkarīgi no dažādiem riskiem. Latvijas iekšējo un ārējo risku apskats ḷauj apzināt izaicinājumus fiskālās ilgtspējas nodrošināšanai nākotnē. Kādi ir valsts fiskālās ilgtspējas riski?

Politiķu pieaugošà vēlme palielināt izdevumus atbalsta pasākumiem, kam ir vāja saistība ar Covid-19 krīzi. Padodoties sabiedrības nogurumam un spiedienam, valdības labi mērḳētais un samērīgais atbalsts kḷūst aizvien apjomīgāks, universālāks un mazāk saistīts ar Covid-19 krīzi. Valsts budžeta deficìts 2021. gadā var sasniegt 9,3\%, valsts parāds - 50\% lìmeni no IKP. Turpmākas attīstības scenāriji paredz, ka Covid-19 krīze 2021. gada beigās tiks pārvarēta un Covid-19 trešais vilnis, ja tāds būs, atstās nenozīmīgu ietekmi uz ekonomiku, un valsts atbalsts tik lielā apjomā nebūs nepieciešams. Tomēr, ṇemot vērā, ka 2022. gadā, visticamāk, nebūs ierobežojumu budžeta izdevumu līmenim, tas varētu veicināt budžeta izdevumu un valsts parāda ekonomiski nepamatotu pieaugumu, it sevišķi 2022. gada Saeimas vēlēšanu kontekstā.

Straujš un ievērojams inflācijas pieaugums, kas rezultēsies paräda apkalpošanas izmaksu pieaugumā, ir viens no lielākajiem biediem valsts finanšu uzraugiem, it sevišķi valstīs ar augstu parāda līmeni. Lai arī inflācijai ir pozitīvs blakusefekts - tas samazina valsts parādu relatīvā izteiksmē, pieaugošās procentu likmes, kas pavada inflāciju, ir daudz nozīmīgāks risks valsts fiskālajai ilgtspējai, jo palielina parāda apkalpošanas izmaksas. Pat neliels pieaugums procentu likmēs ievērojami palielina procentu izdevumus tādām valstīm kā Itālija, kur parāds jau sasniedzis 160\% no IKP. Pēdējās desmitgadēs pasaules ekonomikā ir notikušas strukturālas izmaiṇas, kā dēl vairs nav izteiktas korelācijas starp izlaižu starpību un inflāciju, un dabiskā procentu likme, kad notiek ekonomiskā izaugsme bez ievērojamas inflācijas, ir nokritusies, kā arī ir samazinājusies produktivitāte. Šis ir lāvis attīstīto valstu valdībām īstenot ekspansīvu fiskālo un arī monetāro politiku, kas nav rezultējusies augstā inflācijā un procentu likmēs. Tomēr sociālie un ekonomiskie procesi var negaidīti un strauji mainīties, it sevišḳi mūsu globalizētajā pasaulē. Piemēram, ASV aizvien pieaug bažas par inflācijas pieaugumu, kas rezultējas pieaugošās valsts vērtspapīru procentu likmēs: 10 gadu valsts kases obligācijas ienesīgums 2020. gadā kopš Covid-19 krīzes sākuma pārsvarā svārstijās 0,6-0,9\% robežās, 2021. gada februāra beigās sasniedza 1,54\%, marta beigās jau 
$1,74 \%^{19}$. Šis procenta likmju pieaugums ir licis nervozēt ASV akciju tirgum, kura cenu sabrukums savukārt var būt vēl viens valsts fiskālās ilgtspējas riska avots. Ietekmīgais The Economist ${ }^{20}$ prognozē inflācijas pieaugumu trīs posmos. Pirmajā inflācija automātiski pieaug salīdzinājumā ar 2020. gadu, kad cenas strauji samazinājās ekonomiskā panīkuma dēḷ. Otro inflācijas vilni izraisīs iedzīvotāju aizturētais patēriņš pēc Covid-19 ierobežojumu atcelšanas. To stiprinās ASV iedzīvotājiem piešķirtais 1400 USD pabalsts, kas stimulēs ekonomiku vairāk nekā 8\% apmērā no IKP. Prezidentam Baidenam vēl ir padomā "Amerikas darba vietu plāns" un "Amerikas ğimeņu plāns”, kas palielinātu budžeta izdevumus un stimulētu ekonomiku vairāk nekā 4 miljardu ASV dolāru apmērā. Trešais potenciālais inflācijas posms ir vissvarīgākais, jo tajā izšķirsies, vai pirmo divu posmu pagaidu inflācija rezultēsies pastāvīgā inflācijā, ko rada sabiedrības inflācijas gaidas, kas kḷūst pašpiepildošas (self-fulfilling). Inflācijai ir tendence izplatīties, un strauja ASV inflācija viennozīmīgi tiktu importēta uz mazo, atvērto Latvijas ekonomiku, un ECB būtu spiesta celt arī savas procentu likmes, lai ierobežotu inflācijas izplatību eirozonā.

ES dalībvalstu potenciālās ekonomiskās un politiskās problēmas var ievērojami ietekmēt Latvijas fiskālo situāciju. 2020. gadā palīdzība no ES veidoja 11,3\% no visiem valsts budžeta ien̦ēmumiem. Lìdz ar to esam fiskāli jutīgi pret politiskiem un ekonomiskiem satricinājumiem gan ES dalībvalstīs, gan pašā Eiropas Savienībā, kam ir potenciāls ietekmēt Latvijas dotāciju no ES budžeta. Piemēram, Grieķijai un Itālijai ir milzīgi valsts parādi, kuru apkalpošanas nasta ir cieši saistīta ar inflāciju un procentu likmēm. Nelabvēlīgas ekonomiskās attīstības gadījumā ES varētu būt nepieciešamība glābt tieši šìs vai citas valstis ar lielu parādu, tādējādi mazinot pieejamo finansējumu Latvijai. Turklāt ekonomiskās grūtības rada labu augsni populismam, kura uzvaras gadījumā ekonomiskās problēmas palielinās vēl vairāk. Grieķijas ekonomisko krīzi ar milzīgām grūtībām ir izdevies vismaz apturēt, taču Itālijā tas varētu būt arī neiespējami tās ekonomikas izmēra dēḷ. Lielbritānijas izstāšanās no savienības ir pierādījums, ka fiskālā ietekme ES politisko problēmu dẹl ir realitāte.

Latvijas fiskālais risks, kas izriet no netiešo atbalsta instrumentu sañēmēju $d z \bar{i}$ votspējas. Latvijā valdības atbalsts uzṇēmumiem ir sniegts ne tikai tiešā, bet arī netiešã veidā - garantiju, aizdevumu, nodokḷ samaksas termiṇa pagarināšanas u. c. formās. Gadījumā ja šo atbalsta instrumentu saṇēmējs tomēr bankrotē, valsts budžeta bilance pasliktinās. Pēc Altum datiem, no krīzes sākuma līdz 2021. gada 25. martam finanšu institūcija ir sniegusi gandrīz 900 miljonus eiro lielu atbalstu

19 ASV Valsts kases dati. Pieejams: https://www.treasury.gov/resource-center/data-chart-center/interest-rates/pages/TextView.aspx?data=yieldYear\&year=2020 [skatīts 02.04.2021.]

20 The Economist, 2021, 23. marts, 54. lpp. 
uzņēmējiem dažādu instrumentu formā. Savukārt VID varētu dot nodokḷu nomaksas termiņu pagarinājumu līdz pat 400 miljonu eiro apmērā. Pilnu šo instrumentu un attiecīgo risku ietekmi uz vispārējo valdības budžeta bilanci varēs novērtēt tikai pēc vairākiem gadiem, kad tiem visiem būs beidzies darbības termiņšs.

Latvijas iedzīvotāju demogrāfiskā struktūra ir nozīmīgs fiskālais risks vidējā terminnā. Latvijas iedzīvotāju skaits sarūk jau kopš 1990. gada, palielinās arī iedzīvotāju vidējais vecums. Tam ir divējāds negatīvs fiskālais iespaids - no vienas puses, novecojot sabiedrībai, pieaug medicīnas aprūpes izdevumi un izmaksas pensijām, kurus lielā mērā sedz budžeta dotācijas, no otras - darbaspēka trūkums ietekmē ekonomikas potenciālu un līdz ar to arī nodokḷu ieņēmumus.

Strauji pieaugošās dalības maksas ES budžetā ir arì viens no potenciāliem riskiem. Piedevām šis risks var realizēties dažādu scenāriju gadījumā. Viens no tiem - ambiciozā ES fiskālās centralizācijas projekta - Atveseḷošanas un noturības mehānismam aizṇēmuma atmaksai - nepietiks ES “pašu līdzekḷu”, kas prasa visu dalībvalstu piekrišanu atteikties no saviem potenciāliem nodokḷu ieñēmumiem par labu ES. Tādā gadījumā aizñēmums atmaksu segs no dalībvalstu iemaksu palielinājuma. Faktiski tas nozīmētu ES tālāku fiskālās integrācijas apturēšanu. Vienmēr pastāvēs risks, ka fiskāli konservatīvākās ES nevēlēsies turpmāku fiskālo integrāciju ar valstīm, kam ir izteikti pretēja fiskālā filozofija.

Tomēr dalības maksas ES budžetā var pieaugt arī turpmākas veiksmīgas ES fiskālās centralizācijas gadījumā. Ir jāapzinās, ka tādā situācijā jebkuras ES dalībvalsts fiskālās problēmas automātiski kḷūst arì par Latvijas problēmām. Daudzām ES valstīm ir salīdzinoši augsts parāda līmenis un daudz lielāki fiskālie riski nekā Latvijai, un to potenciālā maksātnespēja var tikt segta no Latvijas nodokḷu maksātāju maka.

\section{Secinājumi}

Valdības fiskālā atbilde uz Covid-19 krīzi ir bijusi adekvāta pirmā viḷņa laikā, bet nedaudz nokavēta un, iespējams, pārmērīga un ne tik labi mērḳēta otrā viḷna periodā. Reitinga kompānijas ir augstu novērtējušas Latvijas valdības fiskālo darbību krīzes laikā, nepazeminot valsts kredītreitingu, kas joprojām ḷauj Valsts kasei aizṇemties starptautiskajos kapitāla tirgos par rekordzemām procentu likmēm. Lai arī joprojām ir liela nenoteiktība ar inficēšanās apkarošanas tempiem, makroekonomiskajiem un fiskālajiem rādītājiem, domājams, ka arī pēc krīzes Latvijas parāds būs zem $60 \%$ no IKP atzīmes. Liela daḷa fiskālo risku ir ārēji, un valdībai ir mazas iespējas tos ietekmēt. Labākā recepte, kā mazināt fiskālos riskus, - arī turpmāk veidot konservatīvu un pretciklisku politiku, kas nodrošinātu drošības spilvenu križu gadījumā. 